\title{
Changes in vegetation cover of the Pantanal wetland detected by Vegetation Index: a strategy for conservation
}

\author{
Ciomara de Souza Miranda ${ }^{I^{*}}$, Antonio Conceição Paranho Filho ${ }^{2}$ \& Arnildo Pott $^{3}$ \\ ${ }^{1}$ Instituto Federal do Mato Grosso do Sul, Aquidauana, MS, Brazil \\ ${ }^{2}$ Universidade Federal de Mato Grosso do Sul, Faculdade de Engenharias, Arquitetura e Urbanismo e Geografia, \\ Laboratório de Geoprocessamento para Aplicações Ambientais, Campo Grande, MS, Brazil \\ ${ }^{3}$ Universidade Federal de Mato Grosso do Sul, PPG Biotecnologia e Biodiversidade, Campo Grande, MS, Brazil \\ *Corresponding author: Ciomara Miranda, e-mail: ciomara.miranda@gmail.com
}

MIRANDA, C. S., PARANHO FILHO, A. C., POTT, A. Changes in vegetation cover of the Pantanal wetland detected by Vegetation Index: a strategy for conservation. Biota Neotropica. 18(1): e20160297. http://dx.doi. org/10.1590/1676-0611-BN-2016-0297

\begin{abstract}
The Brazilian Pantanal wetland undergoes landscape alterations that can cause impacts on hydrological processes, changing the flood pulse. The objective of this work is to analyse the vegetation cover of the Pantanal in the period of 2000, 2008 and 2015, and to make a projection for 2030. Therefore, NDVI from the sensor MODIS was analysed and the transition matrix was calculated by the DINAMICA EGO. The methods adopted were open sources. The results were worrisome, indicating alterations of the vegetation cover of the Pantanal, with an increase of short vegetation (grasslands or pastures) in the evaluated period. The projection pointed out that in 2030 the Brazilian Pantanal wetland area will be covered by $78 \%$ of short vegetation and only $14 \%$ of dense (arboreal-shrubby) vegetation. The approach can be a useful tool for conservation of the Brazilian Pantanal wetland.
\end{abstract}

Keywords: EGO DYNAMICS, wetland, geoprocessing, NDVI, Transition rate.

\section{Mudanças na cobertura da vegetação do Pantanal dectadas por Índice de Vegetação: uma estratégia de conservação}

Resumo: O Pantanal brasileiro sofre alterações em sua paisagem que podem provocar impactos sobre os processos hidrológicos, afetando os pulsos de inundação. O objetivo do trabalho é analisar a cobertura vegetal do Pantanal no período de 2000, 2008 e 2015 e realizar a projeção quantitativa para 2030. Portanto, foram analisados dados NDVI do sensor MODIS e a análise da matriz de transição foi calculada pelo DINAMICA EGO. Os métodos utilizados foram todos em softwares livres. Os resultados foram preocupantes, indicando alteração da cobertura vegetal do Pantanal, com o aumento da vegetação rasteira (campos ou pastagens) no período avaliado. A projeção apontou que em 2030 a área do Pantanal será coberta por 78\% de vegetação rasteira e apenas 14\% de vegetação densa (arbóreo-arbustiva). A abordagem apresentada pode ser uma ferramenta útil para a conservação do Pantanal.

Palavra-chave: Dinamica EGO, área úmida, geoprocessamento, NDVI, taxa de transição.

\section{Introduction}

The structure of ecosystems has changed, mostly in the second half of the 20th century, and mostly all ecosystems were modified by human actions (Hassan et al. 2005). Therefore, many studies and tools that contributes to monitor of ecosystems. Thus, creation of production alternatives towards the valoration of the ecosystems is a strategy for their preservation (Lovins et al. 1999). Wetlands are important natural areas, since they provide services as retention of pluvial waters, improvement of water quality, maintenance of biodiversity, carbon storage and climate regulation (Hassan et al. 2005).

The Brazilian Pantanal wetland has altitudes between 80 and 190 meters above sea level, inside the hydrographic basin of the Upper Paraguay River. Due to its phytogeographic location, the vegetation has elements of four different domains: the Amazon forest (northwest), the Cerrado tropical savanna (east), the Chaco stepic savanna (southwest) and the Atlantic Forest (Pott \& Pott, 2004). It is a complex of floodplains inserted in a large Quaternary sedimentary lowland filled by deposition of alluvial fans of various affluents (Hamilton 2012, Assine 2015). For its particular characteristics, biodiversity and unique landscapes, the Pantanal brings special environmental interest and has outstanding position in the international scenario, besides being one of the largest freshwater wetlands on Earth.

Wetlands such as the Pantanal are being converted into anthropized areas to meet the growing demand for food production (Verhoeven et al. 2010). Such land use changes have a large impact upon the hydrologic processes, affecting the energy and water balances, and the flood pulse in the Brazilian Pantanal wetland (Harris et al. 2006, Goulden et al. 2007; Silva et al. 2011). The traditional fishing and cattle ranching are being replaced by intensive models, with deforestation and alteration of natural areas (MMA 2002). 
The analysis and the monitoring of alterations in vegetation cover are tools that can help to understand the spatial dynamics of the Brazilian Pantanal wetland and offer relevant information to public and private decision makers, who could adopt efficient measures through public policies, programs, projects and others, aiming preservation of the region's landscape and biodiversity. However, monitoring those areas is a difficult task, because of the large size and its difficult access (Pott \& Pott 2004). Thus, the use of remote sensing is essential for monitoring and, consequently, for preservation of the Brazilian Pantanal wetland. Due to the spectral response characteristics of the vegetation it is possible to utilize geoprocessing techniques for its identification and evaluation. An example of such techniques is the vegetation index. The Normalized Difference Vegetation Index (NDVI) is widely utilized in the assessment of several biophysical parameters, such as vegetation coverage, biomass, fraction of the photosynthetically active radiation and phenological variations (Huete et al. 2002; Prabakaran et al. 2013). Furthermore, it is a classic example of vegetation mapping utilizing remote sensing, as it deals with the information from the reflectance in the spectrum range of red and near-infrared wavelengths (Xie et al. 2008).

In this context, our work aims to make a multitemporal analysis of the vegetation cover of the Brazilian Pantanal wetland in the last 15 years, and a quantitative projection for 2030. We emphasize, yet, that to carry out our work, we applied only freely available geotechnologies, to allow the replication of methods proposed in other periods and regions.

\section{Material and Methods}

\section{Study Area}

The study area is the Brazilian Pantanal wetlend, with an area of $138,183 \mathrm{Km}^{2}$, occupying around $40 \%$ of the hydrographic basin of the Upper Paraguay River, located in the states of Mato Grosso and Mato Grosso do Sul, in Central-West region of Brazil (Silva \& Abdon 1998) (figure 1).

\section{Normalized Difference Vegetation Index}

The Normalized Difference Vegetation Index (NDVI), proposed by Rouse et al. (1974), is calculated by the difference of the vegetation reflectances in the near-infrared wavelengths (NIR) and the red wavelengths (equation 1). This difference is then normalized. For being the result of the combination of two bands, the NDVI partially covers-up the effects of atmospheric components and of radiometric and geometric disturbances The NDVI value varies from -1 to +1 .

$$
\mathrm{NDVI}=(\mathrm{NIR}-\mathrm{R}) /(\mathrm{NIR}+\mathrm{R})
$$

where, NIR: Reflectance of the vegetation in the near-infrared wavelength, and R: Reflectance of the vegetation in the red wavelength.

\section{Acquisition of the data base}

To perform our work, we obtained images from the sensor MODIS of the satellite TERRA, product MOD13Q1, quadrants h12v10 and h12v11, available in a 16-day composite of cloud-free images, spatial resolution of $250 \mathrm{~m}$, on the website of the USGS - United States Geological Survey (https://mrtweb.cr.usgs.gov). Among the available scenes, we chose the spectral bands of red (R), near-infrared wavelengths infrared (NIR), and mean infrared (MIR), for elaboration of the false-color compositions, plus the available NDVI (product MOD13Q1). It is interesting to point out that the MODIS products include the geometric and radiometric correction already, which facilitate its utilization. It is also worth mentioning that such images are capable to cover the whole studied region in a single day, preventing seasonal and phenological variations (Paranhos-Filho et al. 2014)

The selected dates were August 12, 2000, August 12, 2008 and August 13, 2015 (USGS, 2000; 2008; 2015), corresponding to the Brazilian Pantanal wetland dry season (from June to September). We performed the conversion of the projection of the acquired scenes to UTM cartographic projection, Datum WGS1984, 21S zone.

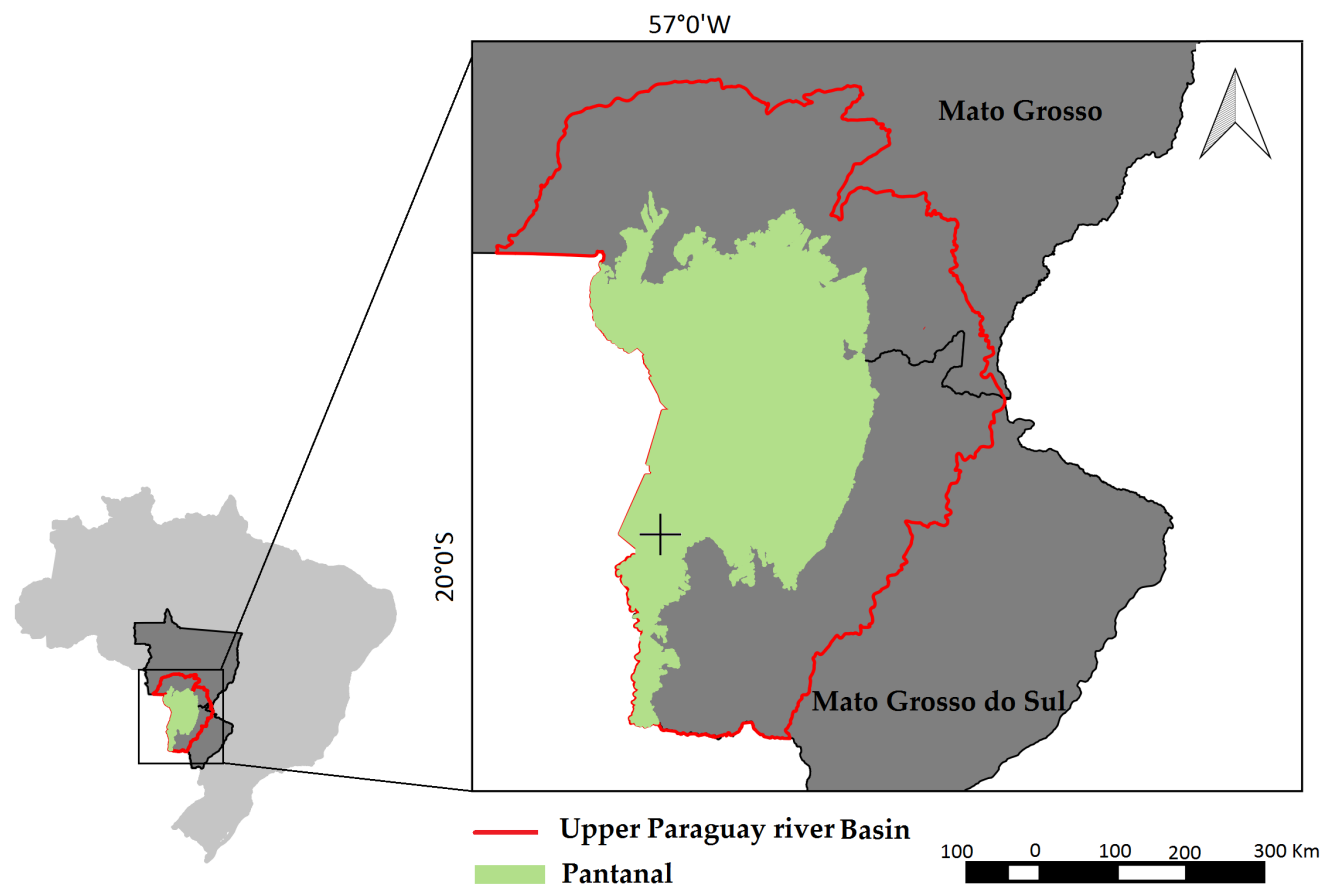

Figure 1. Location of the Brazilian Pantanal plain (in green) inserted in the Upper Paraguay River basin (red limit) (Silva e Abdon, 1998). 
To delimit the vegetation classes, we utilized the vectors of the "Monitoring of Alterations of the Vegetation Cover and Land Use in the Hydrographic Basin of the Upper Paraguay - BAP (Brazilian portion)", which covers the Pantanal, carried out by the Instituto SOS Pantanal and by WWF-Brazil (2015). We looked for support from polygons which would represent the class of interest and did not undergo alteration along the analyzed period in the above-mentioned study.

\section{Analysis of vegetation cover}

We separated the vegetation in three different classes to detect the landscape dynamics: 1) dense vegetation, representing the arboreal/shrubby vegetation, such as woody and forested savanna, formations with fluvial influence, like areas with spectral patterns of tall vegetation without signs of human influence; 2) short vegetation, that indicates the formations of grassy savanna, grasslands, areas with anthropic activities signs and native and tame pastures; 3 ) areas without vegetation like the large water bodies, wet areas, areas with spectral response of bare soil, characteristic of agriculture. Those classes were proposed before by Peres et al. (2016). During the dry season, in August, sandy areas can become overgrazed, with much exposed soil, while near the Paraguay river the lower areas can still be under its delayed flooding (Pott \& Pott, 2004; Hamilton et al. 2002).

The collection of samples of each class was made by interpreting MODIS images from 2000, 2008 and 2015, in the RGB false-color composition, where R - MIR (mean-infrared), G - NIR (near-infrared wavelengths) and B - R (red), considering elements such as texture, color and pattern (Abdon et al., 2007), as well as the polygons derived from the Monitoring of Alterations of the Vegetation Cover and Land Use in the Hydrographic Basin of the Upper Paraguay - BAP (Brazilian portion) (Instituto SOS Pantanal and WWF-Brazil, 2015). After the selection of 7 to 10 samples of each interest class, the samples were overlayed by the NDVI and cropped to obtain its minimum and maximum values, as well as its range index. The NDVI values were reclassified according to the intervals obtained for each encompassed class - the index slicing (Peres et al. 2016). Groupment of the NDVI values in certain intervals were made to represent the evaluated categories for each studied year to obtain distinct and independent values regarding its time basis (Benedetti et al. 2013). All the cited geoprocessing procedures were performed in the open and free GIS, QGIS 2.8 (QGIS Development Team 2015). This work utilized Landsat TM and Landsat 8 images with spatial resolution of $30 \mathrm{~m}$, plus Resource-Sat-1 LISS III images, with spatial resolution of $23.5 \mathrm{~m}$ in several temporal compositions, which provides refined samples of vegetation classes at geographic scale.

We made the calculation of transition matrices between classes with the simulator Dynamic Environment for Geoprocessing Objects - EGO - (2015), a free software, which can model various types of data and evaluate different probabilities of transition with the use of the temporal variable in any number of steps regarding time with a pre-defined transition rate from the transition matrix (Soares-Filho et al. 2006, Soares-Filho et al. 2009, Wang et al. 2016). The calculations were done for the periods 2000-2008, 2008-2015 and 2000-2015, the latter applied in the projection of the changes between classes for 2030 .

The transition rate is one of the keys for modelling, because it determines each soil cover's area undergoing alteration (Elz et al. 2015). The modelling work is a necessary step to verify any possible errors. For that, the values for the classes are confronted with the ones projected by the transition matrix, estimating errors in the modelled transition rates.

\section{Results}

The result of the multitemporal mapping of the vegetation cover derived from NDVI slicing, using maximum and minimum digital value for each class, is shown in figure 2 .

The ranges of values utilized in the identification of the classes are presented in table 1 . We pointed out that the maximum and minimum
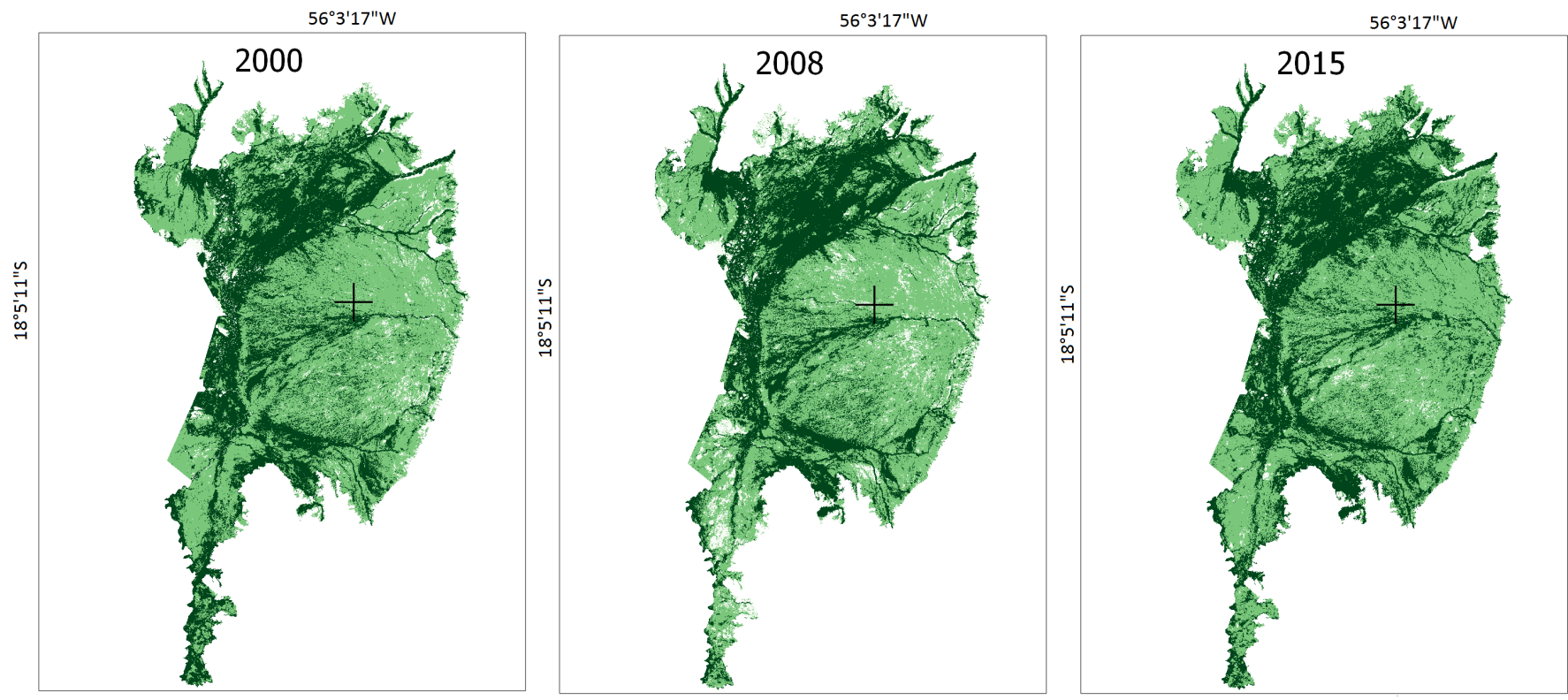

Dense vegetation
Without vegetation

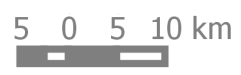

Figure 2. Mapping of the vegetation cover of the Brazilian Pantanal wetland using NDVI recorded in 12/08/2000, 12/08/2008 and 13/08/2015. The darker areas have the highest index value and represent regions covered by denser vegetation. In green, the areas covered by short vegetation, and in white are areas without vegetation. 
Miranda, C.S. et al.

Table 1. Maximum and minimum values of NDVI for each class of vegetation cover for the years 2000, 2008 and 2015 in the Brazilian Pantanal wetland.

\begin{tabular}{|c|c|c|c|c|c|c|}
\hline & \multicolumn{2}{|c|}{2000} & \multicolumn{2}{|c|}{2008} & \multicolumn{2}{|c|}{2015} \\
\hline & Minimum & Maximum & Minimum & Maximum & Minimum & Maximum \\
\hline Dense vegetation & 0.6028 & 1 & 0.5962 & 1 & 0.6643 & 1 \\
\hline Short vegetation & 0.4198 & 0.6027 & 0.4402 & 0.5961 & 0.4429 & 0.6642 \\
\hline Without vegetation & -1 & 0.4197 & -1 & 0.4401 & -1 & 0.4428 \\
\hline
\end{tabular}

Table 2. Areas $\left(\mathrm{Km}^{2}\right)$ of conversion between classes of vegetation cover from 2000 to 2008 and from 2008 to2015 in the Brazilian Pantanal wetland.

\begin{tabular}{|c|c|c|c|}
\hline \multicolumn{4}{|c|}{$2000-2008$} \\
\hline From/To & Dense vegetation & Short vegetation & Without vegetation \\
\hline Dense vegetation & & 11,503 & 697 \\
\hline Short vegetation & 7,448 & & 7,449 \\
\hline Without vegetation & 290 & 3,111 & \\
\hline \multicolumn{4}{|c|}{ 2008-2015 } \\
\hline From/To & Dense vegetation & Short vegetation & Without vegetation \\
\hline Dense vegetation & & 21,979 & 313 \\
\hline Short vegetation & 1,896 & & 4,911 \\
\hline Without vegetation & 62 & 7,654 & \\
\hline
\end{tabular}

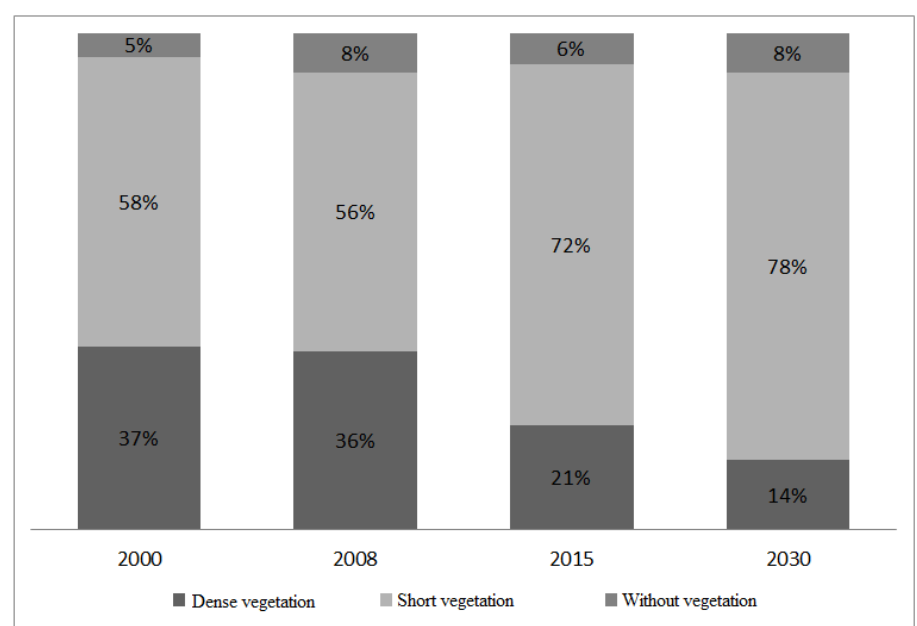

Figure 3. Comparison of the classes of vegetation cover mapped in the Brazilian Pantanal wetland in the years 2000, 2008 and 2015, plus the projection of the behavior of the classes for the year 2030 .

values presented in the table 1 are different, since they were obtained from images of different years (Peres et al. 2016; Benedetti et al. 2013).

The results allowed the quantification of the classes of vegetation cover and the comparison between the years 2000, 2008 and 2015, according to the slicing process (table 1 ). The calculation of the transition rate of 15 years from 2000 to 2015 produced the projection for 2030. The comparison between the area percentage of the vegetation cover classes in the Brazilian Pantanal wetland is shown in figure 3.

Table 2 shows the value in area $\left(\mathrm{Km}^{2}\right)$ regarding conversion processes, reduction and increase between classes, during the period of 2000 to 2008 , and 2008 to 2015 , derived from the rates of the transition matrices generated in the software Dinamica EGO.

The calculations indicated the transition rate of dense to short vegetation and vice-versa of $22.55 \%$ and $13 \%$, respectively, in the period of 2000-2008. In the same period, there was a loss of $1.37 \%$ of dense vegetation to areas without vegetation. The recovery from areas without vegetation to short vegetation and to dense vegetation was of $47.10 \%$ and
$4.40 \%$, respectively. In the period of 2008-2015 the transitions were more expressive if compared with the previous period. The reduction of areas of dense to short vegetation was $44.34 \%$, while the recovery from short to dense vegetation was only $2.46 \%$. The conversion of areas without vegetation to short vegetation was $67.40 \%$. The analysis of the whole period, from 2000 to 2015, shows that the most expressive rates are those of from dense to short vegetation at $4.75 \%$ a year and from an area without vegetation to short vegetation at $6.65 \%$ a year. Elz et al. (2015) recommend a test concerning the error of the calculated rates. The highest difference found was an underestimation of $3 \%$.

\section{Discussion}

The use of geotechnologies allows a holistic analysis in continental wetlands, bringing practical approaches for control, land planning, public policies and conservation practices (Elz et al. 2015). Beside those technologies being used to observe and quantify changes of vegetation cover, it can also monitor the provision of ecosystem services, and a more general utilization can cause positive effect on implementing programs of compensation for ecosystem services, since they provide evidences of the effective supply of services from the Brazilian Pantanal wetland (Alston et al. 2013; Schulz et al. 2015).

In the class of areas "without vegetation" the selected intervals presented values above 0.4 of NDVI for all studied periods, due to the water bodies presenting a wide variation, so the presence of aquatic vegetation could have caused this behavior (Andrade et al. 2012). The flood of the Paraguay River has a delay of 2-3 month in relation to the rainy season, and in August some western areas may be still flooded (Hamilton et al. 2002). Furthermore, the areas interpreted as bare soil are also framed as agricultural areas (Instituto SOS Pantanal \& WWF-Brazil 2015), that in August appear as dry vegetation and exposed soil, what justifies the high values for the category assessed as without vegetation (Andrade et al. 2012).

Our most striking observation in the Brazilian Pantanal wetland was the conversion of the class dense vegetation into short vegetation, a result like the reported by Paranhos et al. (2014) and Peres et al. (2016). Abdon et al. (2007) pointed out the replacement of native grassland by cultivated pasture, in addition to loss of high biomass vegetation, what means alterations of the natural environment. Cardoso et al. (2010) studied the Brazilian Pantanal wetland sub region Nhecolândia and said that the conversion of native forest into cultivated pasture and the continuous 
grazing native grassland reduce stocks of organic and microbial carbon in the soil, notably depleted under older cultivated pastures.

The degradation of the original vegetation in the studied area can be explained by the new tendencies of economic development towards more intensive land use, with deforestations and alteration of natural areas (MMA 2002). Harris et al. (2006) assessed the period of 2000-2004 and estimated a yearly deforestation rate of $2.3 \%$, concluding that in 2051 the original vegetation cover of the Brazilian Pantanal wetland would be completely lost or modified. In their study the suppression projection used mean geometric growth, Silva et al. (2011) estimated that the vegetation cover of the Brazilian Pantanal wetland could be totally lost until 2045.

The change of the vegetation cover in the whole study area (Table 2 and Figure 3) recorded in the period of 2000-2008 points to a reduction and increase between classes in a more balanced way, as we estimated that $12200 \mathrm{Km}^{2}$ of dense vegetation were lost, but $7738 \mathrm{Km}^{2}$ were recovered. The transition of the class without vegetation to dense vegetation between years is observed in areas where previous limits of water bodies were covered by vegetation.

The recovery from short to dense vegetation represents a gain of biomass, probably because of two management systems of cattle ranching: cattle stays year-round (the most common) or the cattle only stays during the dry season and it is removed when flooding begins (Pott, 1994), which allows the recovery of the flooded area. Such management induced changes can be observed on contrasting sides of fence lines. Furthermore, invasive of woody plants, e.g., Vochysia divergens, occurred over grasslands, particularly in the northern part of the Brazilian Pantanal wetland (Junk \& Nunes 2012).

During the period of 2008-2015 the biggest reduction of dense vegetation occurred, summing up $22292 \mathrm{Km}^{2}$. Figure 3 shows the evolution of the short vegetation over the plain, which corroborates numerous studies in the region (Abdon et al. 2007, MMA 2011, Silva et al. 2011, Paranhos et al. 2014, Peres et al. 2016). In our work the projection of the transition between classes shows that in 2030 the Brazilian Pantanal wetland will have $78 \%$ of its area covered by short vegetation and only $14 \%$ by dense vegetation. Such information is an additional justification for more conservative actions on vegetation suppression control in the Brazilian Pantanal wetland. The decisions made by public managers and other decision makers shall be directed to design more effective public policies in controlling and monitoring the Brazilian Pantanal wetland and its basin (Silva et al. 2011). Therefore, the challenge for conservation of the Pantanal consists in new socioeconomic model to compromise environmental protection and land use, with evaluation of ecosystem services, organic production, as well as the valorization of the genetic diversity patrimony (Tocantins et al. 2006, Neves 2009).

\section{Conclusion}

Our work ratifies the alteration of the vegetation cover in the Brazilian Pantanal wetland. If the present pattern continues, the natural vegetation of the Brazilian Pantanal wetland will be mostly lost or modified, in medium time interval, which could seriously affect its climatic-hydrologic dynamics, like change the cycles of floods and droughts (flood pulse), the exuberance of waters and its biological biodiversity.

The contribution of the present work is relevant, beyond the generated products and the applied methods. The results alerts for the need of stricter public policies aiming the conservation and the sustainable use of biodiversity at several administration levels. For being an important ecological area, our study points out the need for preservation of the Brazilian Pantanal wetland biodiversity. We highlight the challenge to transform this biodiversity into opportunity of sustainable development. Thus, this article offers a distinct picture for analysis of the approaches for control, land use planning, public policies and conservation practices.

\section{Acknowledgments}

To the Brazilian research funding agencies CAPES (Coordenação de Aperfeiçoamento de Pessoal de Nível Superior) and FUNDECT (Fundação de Apoio do Desenvolvimento do Ensino, Ciência e Tecnologia do Estado de Mato Grosso do Sul) for scholarhip to C. S. Miranda and to CNPq (Conselho Nacional de Pesquisas e Desenvolvimento Tecnológico) for research grant to ACPF and AP.

\section{Author Contributions}

Arnildo Pott: substantial contribution to data analysis and interpretation, manuscript critical revision and translated of manuscript.

Antonio Conceição Paranhos: contribution to conceived and planned the experiments.

Ciomara de Souza Miranda: contribution to data collection and data analysis. Planned and carried out the simulations and manuscript preparation.

All authors provided critical feedback and helped shape the research, analysis and manuscript.

\section{Conflicts of interest}

The authors declare that they have no conflict of interest related to the publication of this manuscript.

\section{References}

ABDON, M.M., SILVA, J.S.V., SOUZA, I.M., ROMON, V.T., RAMPAZZO, J. \& FERRARI, D.L. 2007. Deforested area in the Pantanal Biome until the year of 2002: Relations with Phytofisiognomy and Counties Limits. Revista Brasileira de Cartografia. 59:17-24.

ALSTON, L. J., ANDERSON, K. \& SMITH, S. M. 2013. Payment for environmental services: Hypotheses and evidence. Cambridge, MA: National Bureau of Economic Research.

ANDRADE, R.G., SEDIYAMA, G.C., PAZ, A.R., LIMA, P.L. \& FACCO, A.G. 2012. Geotechnologies applied to the assessment of biophysical parameters of the Pantanal biome. Pesquisa Agropecuária Brasileira. 47: 1227-1234.

ASSINE, M. L. 2015. Brazilian Pantanal: a large pristine tropical wetland. In Landscapes and Landforms of Brazil, 1st Edition; Vieira, B. C.; Salgado, A. A. R.; Santos, L. J. C. Eds.; Springer: Dordrecht, Netherlands, p.135-146.

BENEDETTI, A.C.P., LIPPERT, D.B., RUDINEY, S.P., ALMEIDA, C.M.; CARDOSO, C.D.V. \& HENDGES, E.R. 2013. Uso do produto MOD13Q1 do sensor Modis para análise temporal e mapeamento das florestas nas Serras do Sudeste e Campanha Meridional do Rio Grande do Sul. Revista Árvore. 37: 459-467.

CARDOSO, E.L., SILVA, M.L.N., SILVA, C.A., CURI, N. \& FREITAS, D.A.F. 2010. Estoques de carbono e nitrogênio em solo sob florestas nativas e pastagens no bioma Pantanal. Pesquisa Agropecuária Brasileira. 45: 1028-1035.

DINAMICA EGO. Dinamica Environment for Geoprocessing Objects. Centro de Sensoriamento Remoto/Universidade Federal de Minas Gerais - Brazil 2015. http://csr.ufmg.br/dinamica/downloads/ (accessed on 20 March, 2015).

ELZ, I.; TANSEY, K.; PAGE, S. E.\& TRIVEDI, M. 2015. Modelling Deforestation and Land Cover Transitions of Tropical Peatlands in Sumatra, Indonesia Using Remote Sensed Land Cover Data Sets. Land. 4: 670-687.

GOULDEN M.L., LITVAK M. \& MILLER S.D. 2007. Fdecision makers that control Typha marsh evapotranspiration. Aquatic Botany. 86: 97-106.

HAMILTON, S. K., SIPPEL, S.J., MELACK, J.M. 2002. Comparison of inundation patterns among major South American Floodplains. Journal of Geophysical Research: 107, 5-14.

HASSAN, R., SCHOLES, R., ASH, N. 2005. Ecosystems and human well-being. Current state and trends. Washington, DC: Island Press.

HARRIS, M.B., ARCÂNGELO, C., PINTO, E.C.T., CAMARGO, G., RAMOSNETO, M.B. \& SILVA, S.M. 2006. Estimativa da perda de cobertura vegetal original na Bacia do Alto Paraguai e Pantanal brasileiro: ameaças e perspectivas. Natureza \& Conservação: 4, 24-49. 
HUETE, A., DIDAN, K., MIUIRA, T., RODRIGUEZ, E.P., GAO, X. \& FERREIRA, L.G. 2002. Overview of the radiometric and biophysical performance of the MODIS vegetation indices. Remote Sensing of Environment. 83:195-213.

JUNK, W.J. \& NUNES, C. 2012. Pasture clearing from invasive woody plants in the Pantanal: a tool for sustainable management or environmental destgruction. Wetlands Ecology and Management. 20: 111-122.

LOVINS, A.B. \& LOVINS, L.H.; HAWKEN, P. 1999. A road Map for Natural Capitalism. Havard Business Review:145-158.

MMA. Ministério do Meio Ambiente. Instituto Brasileiro do Meio Ambiente e dos Recursos Naturais. Monitoramento do desmatamento nos biomas brasileiros por satélite. Monitoramento do bioma Pantanal 2008- 2009. Brasília: MMA/IBAMA/ CID. 2011, 26p. http://www.mma.gov.br/estruturas/sbf_chm_rbbio/_arquivos/ relatrio_tcnico_monitoramento_pantanal_2008_2009_72.pdf (accessed on 15 July 2016).

MMA. Ministério Do Meio Ambiente. Avaliação e identificação de áreas e ações prioritárias para a conservação, utilização sustentável e repartição dos benefícios da biodiversidade nos biomas brasileiros. Brasília: MMA/SBF, 2002. 404 p.

NEVES, A.C.O. 2009. Conservation of the Pantanal Wetlands: The Definitive Moment for Decision Making. AMBIO: A Journal of the Human Environment. 38: 127-128.

PARANHOS-FILHO, A.C., MOREIRA, E.S., OLIVEIRA, A.K.M., PAGOTTO, T.C.S. \& MIOTO, C.L. 2010. Análise da variação da cobertura do solo no Pantanal de 2003 a 2010 através de sensoriamento remoto. Revista de Engenharia Sanitária e Ambiental. 19:69-76.

PERES, P.N., MIOTO, C.L., MARCATO-JUNIOR, J. \& PARANHOS-FILHO, A.C. 2016. Variação da Cobertura do Solo no Pantanal de 2000 a 2015 por Sensoriamento Remoto com Software e Dados Gratuitos. Anuário do Instituto de Geociências: 39, 116-123.

POTT, A. \& POTT, V.J. 2004. Features and conservation of the Brazilian Pantanal wetland. Wetlands Ecology and Management: 12: 547-552.

POTT, A. Ecossistema Pantanal. In: Puignau, J.P. (ed.). Utilización y manejo de pastizales. Montevidéo, 1994, IICA-Procisur, p. 31-44. (IICAProcisur, Diálogos, 40).

PRABAKARAN, C., SINGH, C.P., PANIGRAHY, S. \& PARIHAR, J.S. 2013. Retrieval of forest phenological parameters from remote sensing-based NDVI time-series data. Current Science. 105: 795-802.

QGIS Development Team. QGIS versão 2.8, 2015. Available from: http://www. qgis.org/pt_BR/site/index.html (accessed on 05 March 2015).

ROUSE, J., HAAS, R., SCHELL, J., DEERING, D. \& HARLAN, J. [viewed 6 February 2016] Monitoring the Vernal Advancement of Retrogradation of Natural Vegetation. NASA/GSFC, Type III, Final Report. Greenbelt, MD, Etats-Unis,
1974, 371 p. [online]. Available from: http://ntrs.nasa.gov/archive/nasa/casi. ntrs.nasa.gov/19740008955.pdf

SILVA, J.S.V.,ABDON, M.M., SILVA, S.M.A. \& MORAES, J.A. 2011. Evolution of deforestation in the Brazilian Pantanal and surroundings in the timeframe 1976-2008. Geografia. 36: 35-55.

SILVA, J.S.V. \& ABDON, M.M. 1998. Delimitação do Pantanal Brasileiro e suas sub-regiões. Pesquisa Agropecuária Brasileira. 33: 1703-1711.

SOARES-FILHO, B.S., RODRIGUES, H.O. \& COSTA, W.L. 2009. Modeling Environmental Dynamics With Dinamica EGO, Guidebook. http://csr.ufmg.br/ dinamica/dokuwiki/doku.php? id=tutorial:start (accessed on 20 November, 2015).

SOARES, B.S., NEPSTAD, D.C., CURRAN, L.M., CERQUEIRA, G.C., GARCIA, R.A., RAMOS, C.A., VOLL, E., MCDONALD, A., LEFEBVRE, P. \& SCHLESINGER, P. 2006. Modelling conservation in the Amazon basin. Nature. 440: 520-523.

SOS Pantanal Institute, WWF-Brazil. Monitoramento das alterações da cobertura vegetal e uso da terra na bacia do alto rio Paraguai-Porção Brasileira(período de análise: 2012 a 2014); Brasília, Brasil, 2014.

SCHULZ, C., IORIS, A.A.R., MARTIN-ORTEGA, J. \& GLENK, K. 2015. Prospects for Payments for ecosystem services in the Brazilian Pantanal: A Scenario Analysis. Journal of Environment \& Development. 24: 26-53.

USGS. 2000. United States Geological Survey. Imagens MODIS. Quadrantes h12v10 e h12v11. Datas de Passagem 12 de agosto de 2000.

USGS. 2008. United States Geological Survey. Imagens MODIS. Quadrantes h12v10 e h12v11. Datas de Passagem 12 de agosto de 2008.

USGS. 2015. United States Geological Survey. Imagens MODIS. Quadrantes h12v10 e h12v11. Datas de Passagem 13 de agosto de 2015.

VERHOEVEN, J.T.A., SETTER, T.L. 2010. Agricultural use of wetlands: Opportunities and limitations. Ann. Bot. 105: 155-163.

WANG, L., YOUNG, S.S.,WANG, W., REN, G., XIAO, W., LONG, Y., LI, J. \& ZHU, J. 2016. Conservation priorities of forest ecosystems with evaluations of connectivity and future threats: Implications in the Eastern Himalaya of China. Biological Conservation.195: 128-135.

XIE, Y., SHA, Z. \&YU, M. 2008. Remote sensing imagery in vegetation mapping: a review. Journal of Plant Ecology. 01: 39-53.

Received: 04/11/2016

Revised: 18/10/2017

Accepted: 09/12/2017

Published online: 08/01/2018 